\title{
Ageing Effects on Microstructure, Mechanical Properties, and Fracture Behaviour of 9Cr-1.5Mo-1Co-VNbBN Martensitic Steel Welded Joint for High Temperature Application
}

\author{
Ladislav Falat, ${ }^{1}$ Viera Homolová, ${ }^{1}$ Lucia Čiripová, ${ }^{1}$ Peter Ševc, ${ }^{1}$ and Milan Svoboda ${ }^{2}$ \\ ${ }^{1}$ Institute of Materials Research, Slovak Academy of Sciences, Watsonova 47, 04001 Košice, Slovakia \\ ${ }^{2}$ Institute of Physics of Materials, Academy of Sciences of the Czech Republic, Žižkova 22, 61662 Brno, Czech Republic \\ Correspondence should be addressed to Ladislav Falat; lfalat@imr.saske.sk
}

Received 3 October 2016; Accepted 10 January 2017; Published 31 January 2017

Academic Editor: Akihiko Kimura

Copyright (C) 2017 Ladislav Falat et al. This is an open access article distributed under the Creative Commons Attribution License, which permits unrestricted use, distribution, and reproduction in any medium, provided the original work is properly cited.

\begin{abstract}
This paper deals with long-term ageing effects of 9Cr-1.5Mo-1Co-VNbBN (CB2) steel weldment on its impact toughness, creep rupture behaviour, and hardness in relation to microstructure and fracture characteristics. The weldment was studied in PWHT state and after isothermal expositions at $625^{\circ} \mathrm{C}$ for 10000 and 30000 hours. Microstructure evolution was studied using analytical scanning and transmission electron microscopy. Charpy V-notch impact toughness tests were performed for all heat-treated states with a notch location in distinct weld regions such as weld metal (WM), heat-affected zone (HAZ), and base material (BM). The overheated HAZ region exhibited the lowest impact toughness as a result of severe welding induced microstructure degradation. Creep tests were performed at $625^{\circ} \mathrm{C}$ in the stress range between 80 and $120 \mathrm{MPa}$. At the highest applied stress, creep fracture occurred in WM, whereas at lower stresses the failure position shifted towards fusion zone at WM/HAZ interface. The hardness profiles experienced significant scattering due to weld microstructural heterogeneity. The major fracture mechanisms involved transgranular quasi cleavage and intergranular creep cracking in impact and creep loading conditions, respectively.
\end{abstract}

\section{Introduction}

The welded joints of high chromium tempered martensitic creep-resistant steel are frequently employed in construction of modern fossil-fired thermal power plants operating at supercritical and ultrasupercritical conditions [1]. Their main application area covers structural parts of thick section boiler components including high temperature header section and main steam pipelines [2-4]. It generally holds that local microstructure formation of individual weld regions, namely, the weld metal (WM), fusion zone (FZ), and heataffected zone (HAZ) depends on their location within the weldment and reached peak temperature during the weld preparation. Due to the presence of microstructural gradient and welding-related residual stresses in welded joints of martensitic/ferritic power plant steel, it is necessary to perform their postweld heat treatment (PWHT). Beside thermal stabilization of initial weld microstructure and residual stress relief, the application of PWHT decreases unallowably high hardness in $\mathrm{FZ}$ and increases the weldments toughness [2, $5,6]$. Worldwide constant efforts are still being put into developments aiming for creep strength improvement of these materials. Apart from classical strengthening mechanisms, such as solid solution, precipitation, and subboundary strengthening, Abe et al. [7] revealed specific boron strengthening mechanism in weldments of Japanese boron alloyed 9Cr-3W-3Co-VNbBN (MARBN) martensitic steel based on the HAZ microstructure modification via boron related effects on the retardation of secondary precipitates coarsening and suppression of diffusive ferrite-to-austenite phase transformation during welding. The European research initiatives in the frame of international collaboration within COST Action 536 resulted in the development of a series $9 \mathrm{Cr}-\mathrm{Mo}-\mathrm{Co}-\mathrm{B}-\mathrm{VNbBN}$ model alloys for production of thick castings and forgings intended for the use at supercritical steam conditions [8]. One of them is represented by $9 \mathrm{Cr}$ $1.5 \mathrm{Mo}-1 \mathrm{Co}-\mathrm{VNbBN}$ (CB2) steel with controlled boron and nitrogen content. 
TABLE 1: Chemical composition in wt.\% of CB2 steel BM and FM (Thermanit MTS 5 Co 1).

\begin{tabular}{ccccccccccccccc}
\hline & $\mathrm{C}$ & $\mathrm{Si}$ & $\mathrm{Mn}$ & $\mathrm{Cr}$ & $\mathrm{Ni}$ & $\mathrm{Mo}$ & $\mathrm{V}$ & $\mathrm{Ti}$ & $\mathrm{Al}$ & $\mathrm{Co}$ & $\mathrm{Nb}$ & $\mathrm{B}$ & $\mathrm{N}$ & $\mathrm{Fe}$ \\
\hline $\mathrm{BM}$ & 0.12 & 0.29 & 0.86 & 9.14 & 0.22 & 1.5 & 0.19 & 0.002 & 0.006 & 0.95 & 0.06 & 0.012 & 0.020 & Balance \\
$\mathrm{FM}$ & 0.11 & 0.45 & 0.65 & 9.10 & 0.7 & 1.3 & 0.24 & 0.01 & 0.01 & 1.09 & 0.06 & 0.003 & 0.028 & Balance \\
\hline
\end{tabular}

Our previous works $[9,10]$ were focused on preliminary studies of ageing effects of thick-walled CB2 weldments with respect to thermal stability of their microstructures and local mechanical properties in different loading conditions. The present study represents an extended and continuing research work aiming for deeper investigation and interpretation of the effects of long-term ageing expositions on mechanical and creep properties variations of the same CB2 steel weldment in relation to its detailed microstructural and fracture characteristics.

\section{Experimental Material and Procedure}

The welded joint of cast 9Cr-1.5Mo-1Co-VNbBN (CB2) steel was produced by tungsten inert gas (TIG) welding using electrode weaving technique and modified filler metal Thermanit MTS 5 Col at PHB Stahlguss International. The thickness of welded plates was around $98 \mathrm{~mm}$. Both the base material (BM) and filler metal (FM) chemical composition is given in Table 1. After the weld preparation, subsequent postweld heat treatment (PWHT) was carried out industrially at $730^{\circ} \mathrm{C}$ for $24 \mathrm{~h}$ by the weld producer. Cross-weld segments obtained within COST Action 536 collaboration were afterwards longterm isothermally aged at $625^{\circ} \mathrm{C}$ for 10 and 30 thousand hours in our laboratory conditions. Charpy V-notch (CVN) samples with dimensions of $10 \times 10 \times 55 \mathrm{~mm}$ and the notch individually located in the BM, WM, and overheated HAZ next to $\mathrm{FZ}$ were used to test impact toughness after long-term ageing expositions and in the PWHT state, as well. The tests were performed at room temperature (RT) for all the material states. After the preageing at $625^{\circ} \mathrm{C}$ for $30 \mathrm{kh}$, the samples were impact tested also at $100^{\circ} \mathrm{C}$. Creep rupture tests were carried out at $625^{\circ} \mathrm{C}$ with applied stresses of 80,100 , and $120 \mathrm{MPa}$ using round M8 tensile creep specimens with gauge length of $40 \mathrm{~mm}$ and body diameter of $5.5 \mathrm{~mm}$. Cross-weld creep tests were performed for the weldments in initial PWHT state and separately also for the welds preaged at $625^{\circ} \mathrm{C}$ for $30 \mathrm{kh}$. The BM preaged in the same way was also creep tested for reference. Hardness HV10 profiles were measured for as-crept material states across the welded joint samples. The microstructure of individual experimental states was observed and analyzed by means of light microscopy (LM) and scanning and transmission electron microscopy (SEM, TEM) equipped with energy dispersive X-ray (EDX) analyzer. Carbon extraction replicas were used for semiquantitative chemical microanalyses of metallic elements in extracted secondary phase precipitates. Experimental results of the phase analyses have been compared with those obtained by thermodynamic calculations using Thermo-Calc Classic software [11] and noncommercial database Steel 16 formulated by Kroupa et al. [12]. Fractographic studies included fracture path and fracture surface observations using LM and SEM.

\section{Results and Discussion}

3.1. Microstructure and Phase Analysis. Overall microstructural features of individual weld regions of studied CB2 weldment in the initial PWHT state are shown on light-optical micrographs in Figure 1. Generally, all the microstructures consist of tempered martensite with precipitated particles of secondary phases occurring within matrix as well as on all types of inner microstructural interfaces such as the primary austenitic grain boundaries, block, packet, and lath subboundaries. Apart from these common features, the microstructures of individual weld regions possess their own specific microstructural characteristics. The original cast, normalized and tempered martensitic microstructure of BM shows noticeably coarse grains and laths (Figure 1(a)), whereas the remelted microstructure of WM (Figure 1(b)) is significantly refined due to its fast cooling during the welding. Transition region between the BM and WM is represented by notably heterogeneous HAZ microstructure following the locality of weld FZ (Figure 1(c)). Beside its heterogeneous grain size, the transition zone exhibits some minor occurrence of nonequilibrium $\delta$-ferrite grains appearing like small precipitate-free areas (see Figure 1(c)). More detailed microstructures of BM and WM in PWHT state and also in long-term aged states at $625^{\circ} \mathrm{C}$ for 10 and 30 thousand hours are visualized on SEM-micrographs in Figures 2-4. In comparison to the microstructures in PWHT state (Figure 2), the microstructures after long-term ageing expositions (Figures 3 and 4) can be characterized by additional precipitation and coarsening of secondary phase particles accompanied by proceeding recovery processes of highly tempered martensitic matrix. The differences in size, morphology, and distribution of secondary precipitates occurring in PWHT state and after the $625^{\circ} \mathrm{C}$ ageing for $30 \mathrm{kh}$ are shown on TEM carbon extraction replicas for BM (Figure 5) and WM (Figure 6).

Phase analyses of individual precipitates on the TEM replicas were performed by their semiquantitative chemical microanalyses via local EDX measurements. The results are given in Table 2 in the form of mean chemical composition (metallic part) in at.\% of individual precipitated phases. In addition, thermodynamic calculations of equilibrium phase compositions were calculated to support the experimental findings. According to the results presented in Table 2, only two types of the precipitates were revealed in PWHT state (Figure 2), namely, fine intragranular MX carbonitrides $(\mathrm{M}=$ $\mathrm{V}, \mathrm{Nb}, \mathrm{Cr} ; \mathrm{X}=\mathrm{C}, \mathrm{N}$ ) at tempered martensitic lath boundaries and large intergranular Cr-rich $\mathrm{M}_{23} \mathrm{C}_{6}$ carbides at grain, block, and packet boundaries. Both of these precipitate types exhibit similar greyish appearance by their SEM visualization using back-scattered electrons contrast (see Figures 2(b) and $2(\mathrm{~d})$ ). On the other hand, during subsequent long-term 


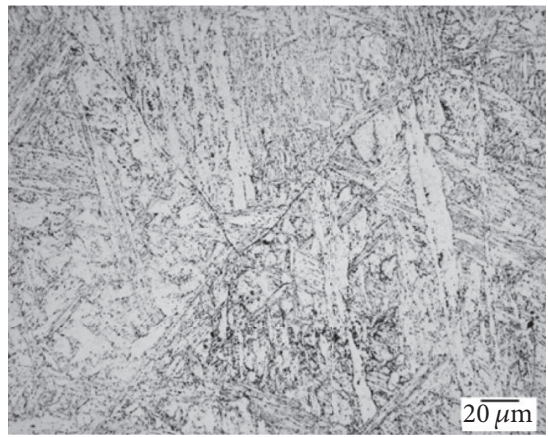

(a)

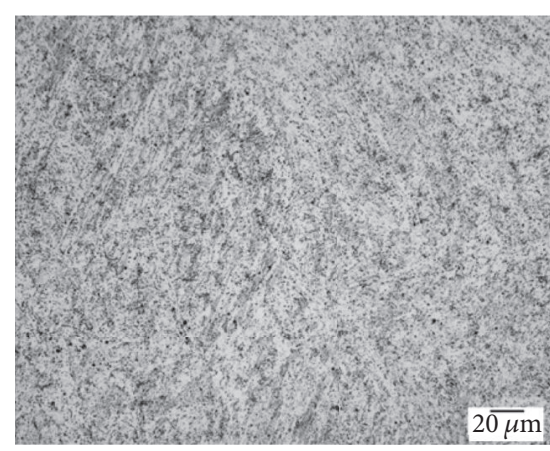

(b)

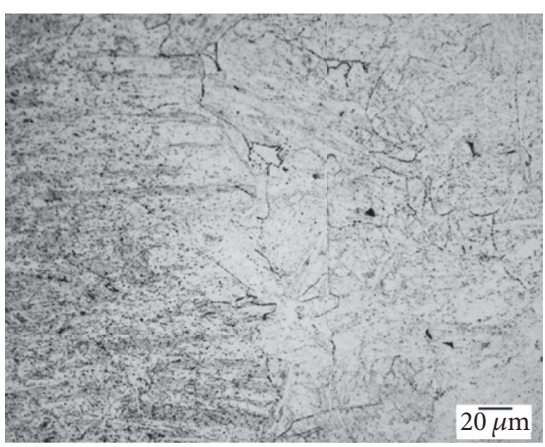

(c)

FIGURE 1: Light-optical microstructures of individual regions of studied CB2 weldment in PWHT state: BM (a), WM (b), and HAZ (c).

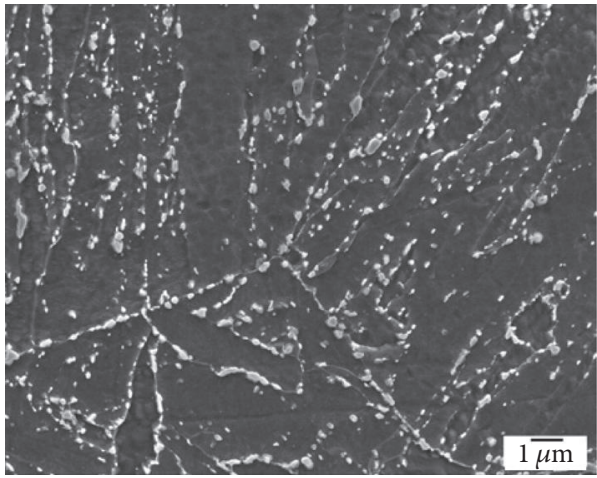

(a)

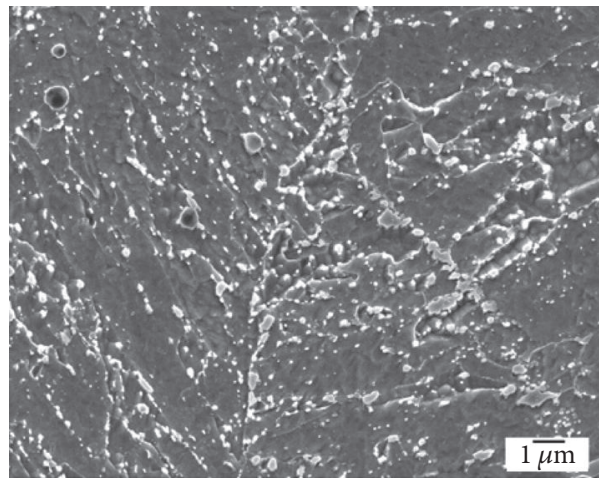

(c)

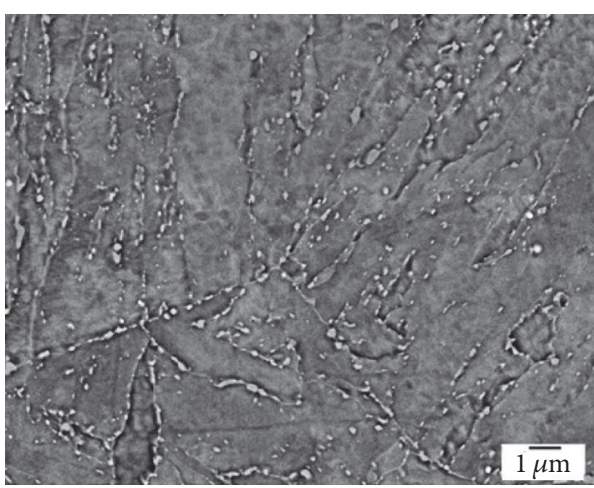

(b)

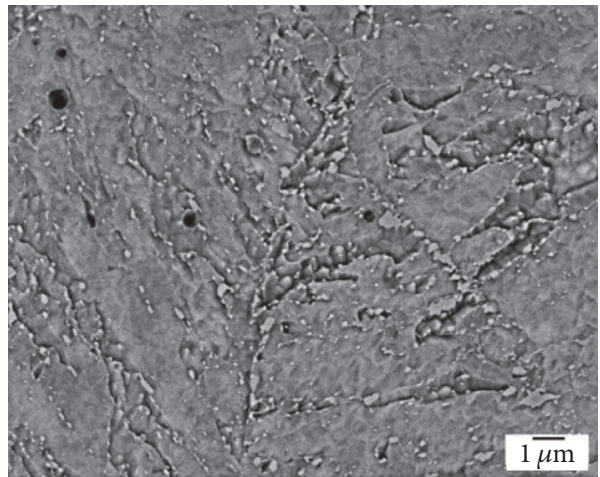

(d)

FIGURE 2: SEM-micrographs of initial PWHT microstructures of BM ( $a, b)$ and WM (c, d) of the CB2 weldment visualized using secondary electrons ( $a, c)$ and back-scattered electrons $(b, d)$.

ageing at $625^{\circ} \mathrm{C}$ for both time durations, the particles of $(\mathrm{Fe}, \mathrm{Cr})_{2} \mathrm{Mo}$ based Laves phase have been revealed, often in the vicinity of $\mathrm{Cr}$-rich $\mathrm{M}_{23} \mathrm{C}_{6}$ carbides (see Figures 3 and 4 and Table 2). These intermetallic precipitates show clear bright appearance in the SEM visualization using backscattered electrons contrast (Figures 3(b), 3(d), 4(b), and $4(d)$ ) due to their notable molybdenum content and thus much higher average atomic number compared to other precipitated phases in the microstructures. The precipitation of Laves phase belongs to the most significant microstructural changes in 9Cr creep-resistant steel during its long-term thermal or creep exposure [13-15]. Furthermore, as indicated in present study by both the experimental measurements and thermodynamic calculations (Table 2), beside the Laves phase also some other newly precipitated phases, namely, the $\mathrm{Cr}(\mathrm{V}, \mathrm{Nb}) \mathrm{N}$ type $\mathrm{Z}$-phase and $\mathrm{Nb}$-rich MC carbides, have been revealed in thermally exposed state at $625^{\circ} \mathrm{C}$ for $30 \mathrm{kh}$ hours. As visible in Table 2, several thermally induced changes in chemical composition of individual phases took place during the ageing: the MX precipitates represented by $(\mathrm{V}, \mathrm{Nb}, \mathrm{Cr})$ rich carbonitrides show certain small enrichment in vanadium and iron at the expense of 


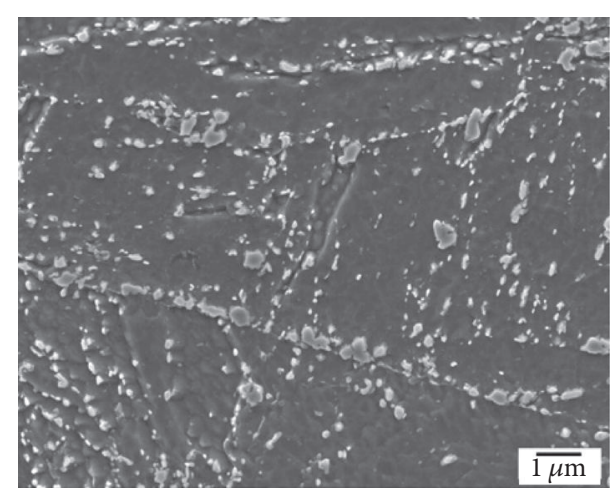

(a)

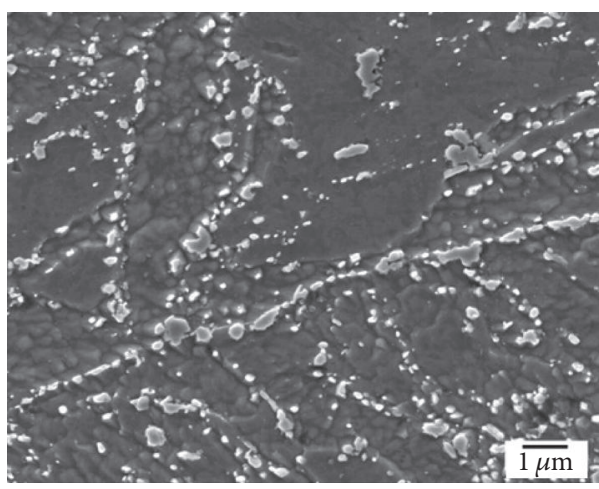

(c)

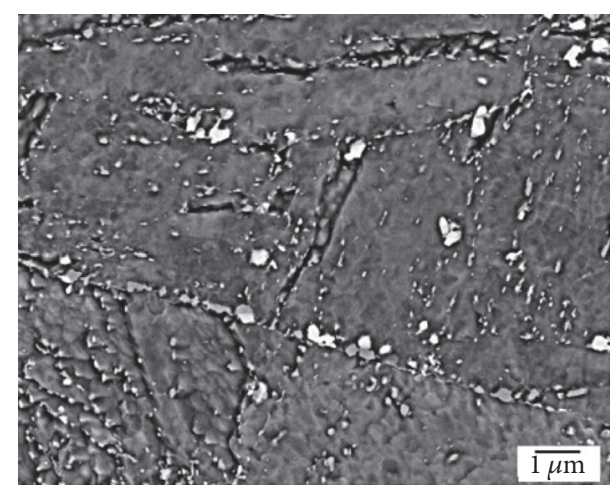

(b)

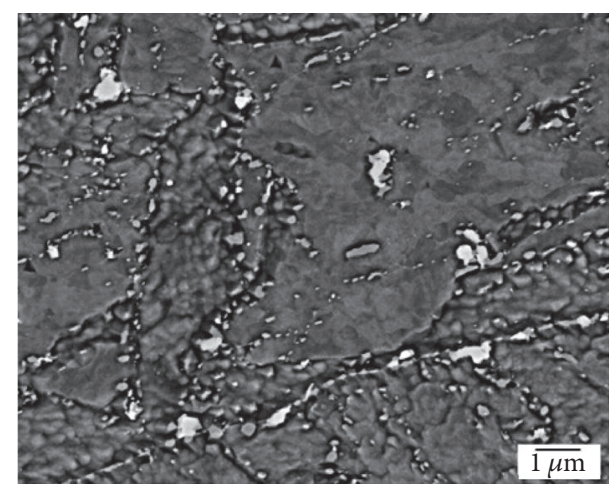

(d)

Figure 3: SEM-micrographs of thermally exposed microstructures at $625^{\circ} \mathrm{C}$ for $10 \mathrm{kh}$ of $\mathrm{BM}(\mathrm{a}, \mathrm{b})$ and WM (c, d) of the CB2 weldment visualized using secondary electrons (a, c) and back-scattered electrons (b, d).

TABLE 2: Mean chemical composition (metallic part) in at.\% of precipitate phases in CB2 weld regions and material states and calculated equilibrium phase composition at $625^{\circ} \mathrm{C}$.

\begin{tabular}{|c|c|c|c|c|c|c|c|c|c|c|c|}
\hline \multirow{2}{*}{ Material state } & \multirow{2}{*}{ Phase } & \multicolumn{5}{|c|}{$\mathrm{BM}$} & \multicolumn{5}{|c|}{ WM } \\
\hline & & $\mathrm{V}$ & $\mathrm{Cr}$ & $\mathrm{Fe}$ & $\mathrm{Nb}$ & Mo & $\mathrm{V}$ & $\mathrm{Cr}$ & $\mathrm{Fe}$ & $\mathrm{Nb}$ & Mo \\
\hline \multirow{2}{*}{ PWHT $\left(730^{\circ} \mathrm{C} / 24 \mathrm{~h}\right)$} & $\mathrm{MX}$ & 62 & 17 & 5 & 14 & 2 & 60 & 15 & 1 & 22 & 2 \\
\hline & $\mathrm{M}_{23} \mathrm{C}_{6}$ & 3 & 65 & 23 & 1 & 8 & 2 & 63 & 27 & 1 & 7 \\
\hline \multirow{5}{*}{ Isothermally aged $\left(625^{\circ} \mathrm{C} / 30 \mathrm{kh}\right)$} & MX & 64 & 14 & 8 & 12 & 2 & 65 & 15 & 3 & 15 & 2 \\
\hline & $\mathrm{M}_{23} \mathrm{C}_{6}$ & 2 & 67 & 23 & 1 & 7 & 2 & 69 & 21 & 1 & 7 \\
\hline & Laves phase & 1 & 14 & 50 & 2 & 33 & 1 & 18 & 46 & 2 & 33 \\
\hline & Z-phase & 39 & 33 & 13 & 11 & 4 & 39 & 40 & 10 & 6 & 5 \\
\hline & $\mathrm{MC}$ & 22 & 18 & 3 & 53 & 4 & 22 & 17 & 2 & 54 & 5 \\
\hline \multirow{4}{*}{ Equilibrium calculatedat $625^{\circ} \mathrm{C}$} & $\mathrm{M}_{23} \mathrm{C}_{6}$ & 3 & 74 & 17 & 0 & 6 & 3.3 & 73 & 17.7 & 0 & 6 \\
\hline & Laves phase ${ }^{*}$ & 0 & 16 & 46 & 0 & 33.3 & 0 & 15.3 & 46 & 0 & 33.5 \\
\hline & Z-phase & 35 & 43.5 & 6.5 & 15 & 0 & 38 & 43.7 & 6 & 12.3 & 0 \\
\hline & $\mathrm{MC}$ & 10.1 & 0.2 & 0 & 89.2 & 0.5 & 12.8 & 0.2 & 0 & 86.5 & 0.5 \\
\hline
\end{tabular}

${ }^{*}$ Containing also 4.7 at. $\% \mathrm{Si}$ in $\mathrm{BM}$ and 5.2 at.\% $\mathrm{Si}$ in WM.

niobium and chromium. Starting from the initial PWHT state followed by long-term ageing up to achievement of equilibrium condition, the $\mathrm{M}_{23} \mathrm{C}_{6}$ precipitates exhibit gradual increasing in their chromium content at the expense of other alloying elements. Experimentally determined Laves phase composition is almost identical with the calculated one (Table 2). As already shown before (Figures 3-6), the longterm ageing expositions of $\mathrm{CB} 2$ weldment at $625^{\circ} \mathrm{C}$ resulted in significant occurrence of coarse Laves phase precipitates. In contrast, only a few Z-phase particles were revealed in studied weldment after the ageing at $625^{\circ} \mathrm{C}$ for $30 \mathrm{kh}$. The observation of Z-phase was also reported by Jandová et al. [16] for the CB2 steel material after its long-term creep exposure at $650^{\circ} \mathrm{C}$. Depending on the occurrence in either BM or WM, the $\mathrm{Z}$-phase precipitates exhibited some small variations in their chemical composition (Table 2). The calculated Z-phase 


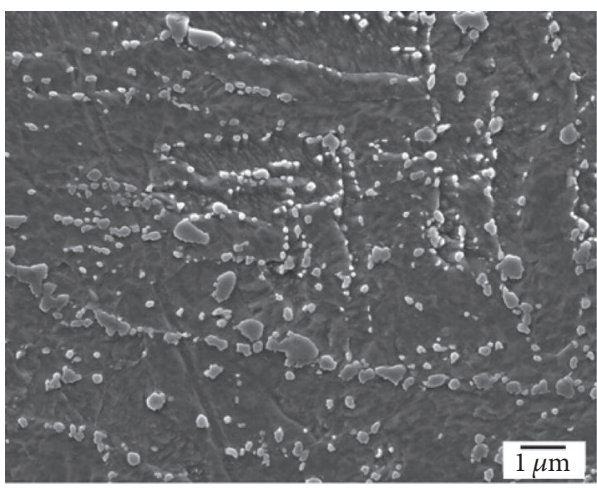

(a)

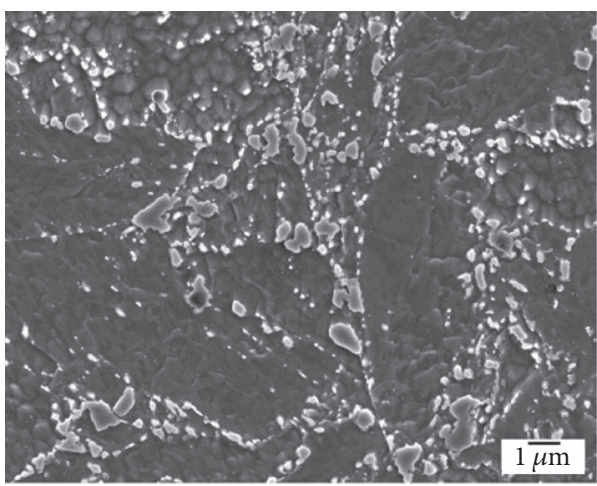

(c)

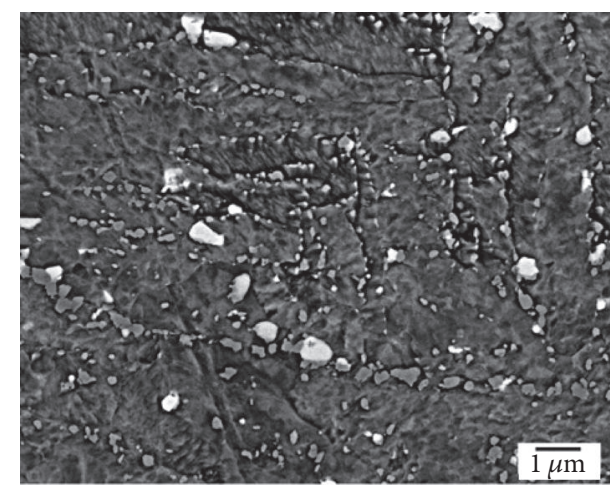

(b)

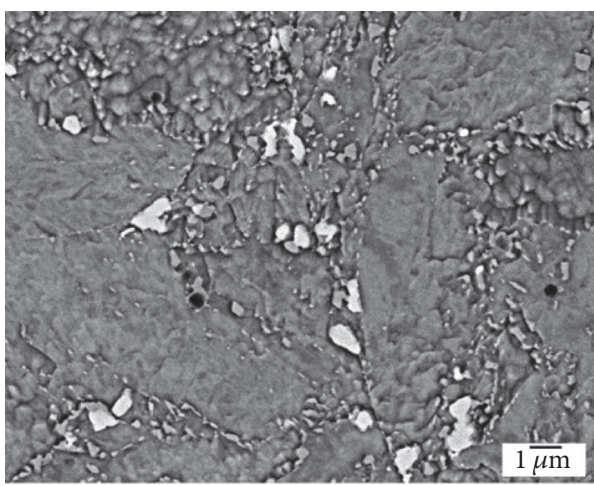

(d)

FIgURE 4: SEM-micrographs of thermally exposed microstructures at $625^{\circ} \mathrm{C}$ for $30 \mathrm{kh}$ of BM (a, b) and WM (c, d) of the CB2 weldment visualized using secondary electrons $(a, c)$ and back-scattered electrons $(b, d)$.

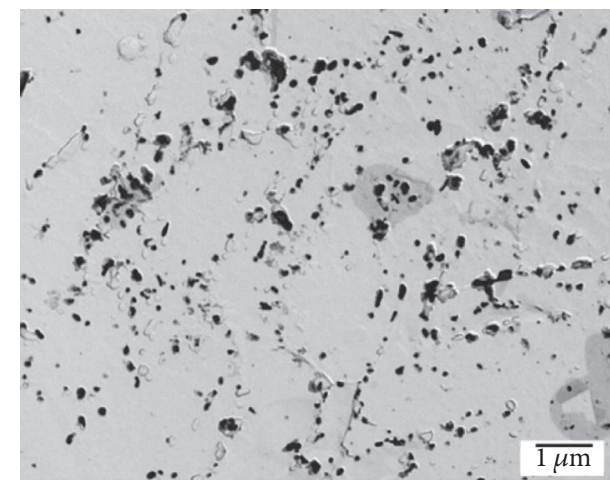

(a)

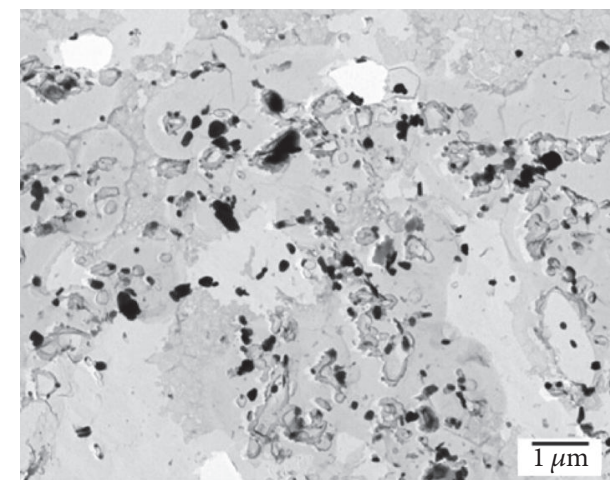

(b)

FIGURE 5: TEM carbon extraction replica visualization of secondary phase precipitates in BM of studied CB2 weldment in PWHT state (a) and after $30 \mathrm{kh}$ ageing at $625^{\circ} \mathrm{C} \mathrm{(b).}$

equilibrium compositions expressed by the metallic elements ratio to be $43.5 \mathrm{Cr}-35 \mathrm{~V}-15 \mathrm{Nb}-6.5 \mathrm{Fe}$ for $\mathrm{CB} 2 \mathrm{BM}$ and $43.7 \mathrm{Cr}$ $38 \mathrm{~V}-12.3 \mathrm{Nb}-6 \mathrm{Fe}$ for CB2 WM (Table 2) correspond well with the findings by Panait et al. [17] for P91 steel base material. In present study, the experimentally determined Z-phase metallic elements ratios were $33 \mathrm{Cr}-39 \mathrm{~V}-11 \mathrm{Nb}-13 \mathrm{Fe}-4 \mathrm{Mo}$ and $40 \mathrm{Cr}-39 \mathrm{~V}-6 \mathrm{Nb}-10 \mathrm{Fe}-5 \mathrm{Mo}$ for the long-term aged $\mathrm{BM}$ and WM, respectively. Such closely similar vanadium content of experimentally analyzed Z-phase precipitates like that of the calculated ones may indicate their early stage of precipitation at the V-rich MX precipitates which also agrees with other observations performed on thermally exposed 9-12Cr steel $[18,19]$. Figure 7 shows temperature dependencies of equilibrium mole fractions of individual phases in CB2 BM and WM obtained by thermodynamic calculations for the temperature range from $400^{\circ} \mathrm{C}$ to $1000^{\circ} \mathrm{C}$. As it can be seen, the highest phase amount in equilibrium at $625^{\circ} \mathrm{C}$ is reached by Cr-rich $\mathrm{M}_{23} \mathrm{C}_{6}$ carbide. The Laves phase achieves the second highest 


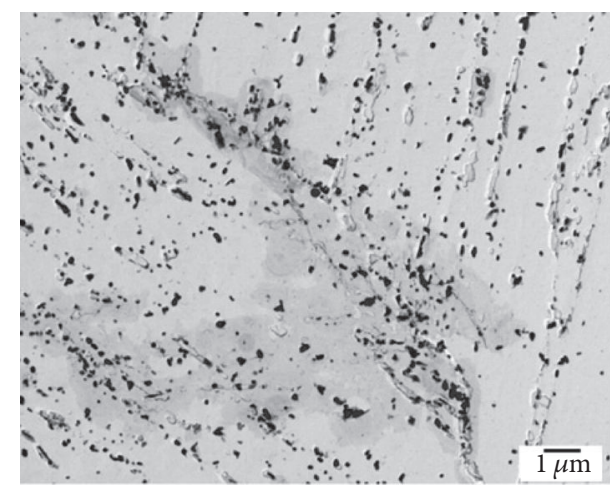

(a)

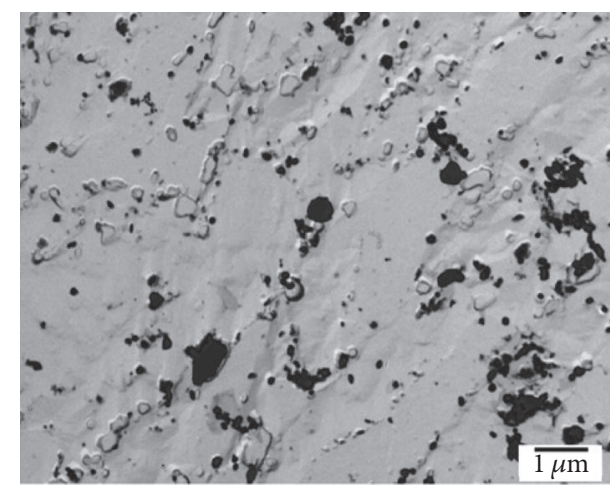

(b)

FIGURE 6: TEM carbon extraction replica visualization of secondary phase precipitates in WM of studied CB2 weldment in PWHT state (a) and after $30 \mathrm{kh}$ ageing at $625^{\circ} \mathrm{C}(\mathrm{b})$.

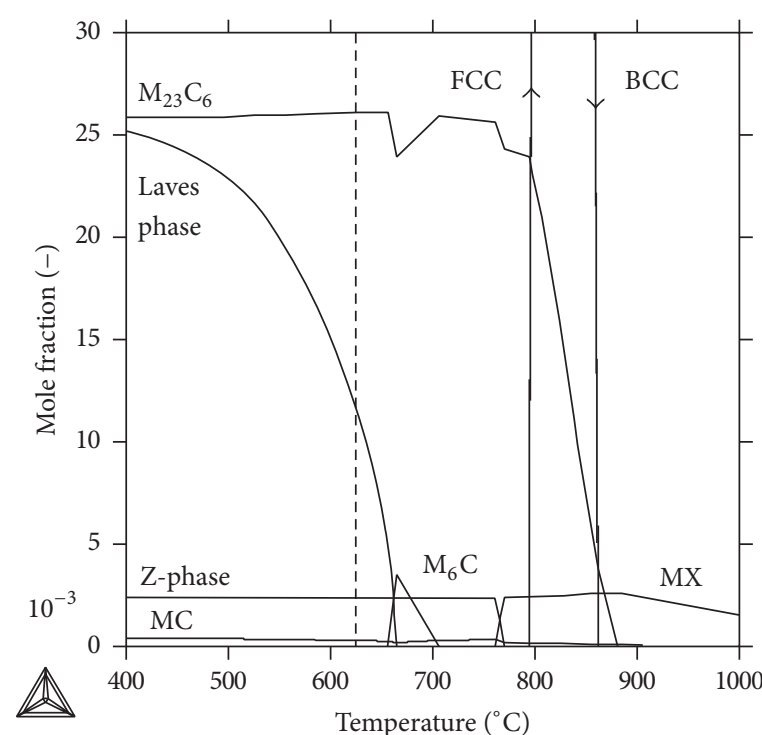

(a)

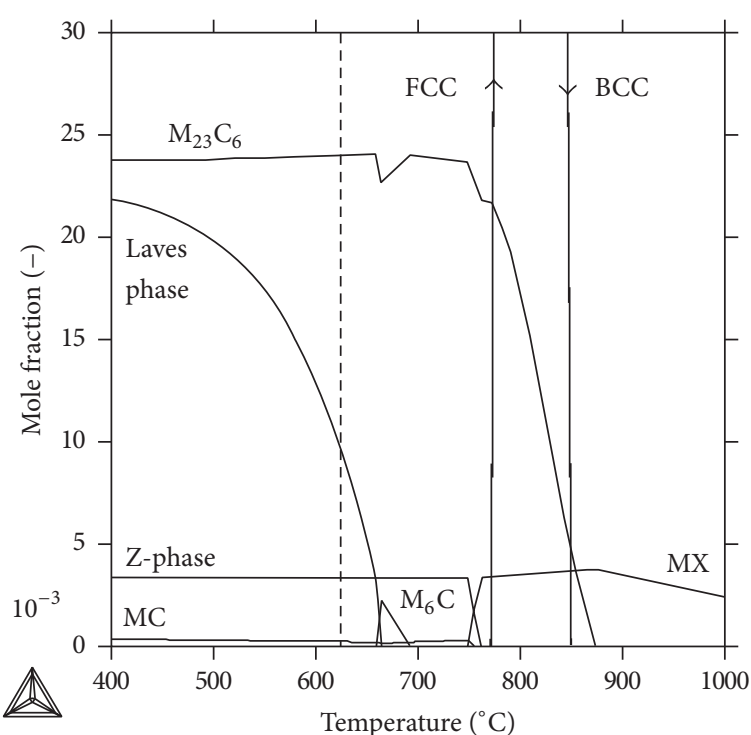

(b)

FIGURE 7: Temperature dependence of mole fractions of equilibrium phases occurring in CB2 steel BM (a) and WM (b).

amount at considered condition. Although the Z-phase and $\mathrm{MC}$ carbides exhibit the lowest phase amounts in the CB2 microstructure, their influence on resulting mechanical properties is not insignificant. Detrimental effects of the Zphase particles coarsening on creep strength are generally known to be directly related to gradual dissolution of fine MX precipitates [19-21] that do not represent the stable phase in $\mathrm{CB} 2$ material at $625^{\circ} \mathrm{C}$ (see Figure 7).

\subsection{Mechanical Properties and Fractography}

3.2.1. Impact Toughness Test. The results of impact toughness tests are shown in Figure 8. The highest room-temperature (RT) impact toughness (i.e., CVN) value of all the tested weld regions in PWHT state was measured in the WM. The main reasons for the highest WM toughness in PWHT state might be related to its finer initial microstructure (Figure 1(b)), lower boron, and higher nickel content in the used FM compared to the CB2 BM (Table 1). The presence of hard nonmetallic globular inclusions in the WM (Figures 2(c) and 2(d)) might also enhance its toughness by promotion of ductile dimples formation. The use of electrode weaving "temper-bead" TIG welding procedure in present case of CB2 weld preparation could also contribute to the higher WM toughness. In contrast, the overheated HAZ region exhibited the lowest impact toughness as a result of severe welding induced microstructure degradation (Figure 1(c)). By comparing the individual material states with respect to the ageing conditions (PWHT, $625^{\circ} \mathrm{C} / 10 \mathrm{kh}, 625^{\circ} \mathrm{C} / 30 \mathrm{kh}$ ), it can be stated that the CVN values measured at RT show their significant and mutually similar decrease for both of the long-term aged states compared to the initial PWHT state (Figure 8). In general, the decrease of RT impact toughness in creep-resistant steel can mainly be attributed to thermal 


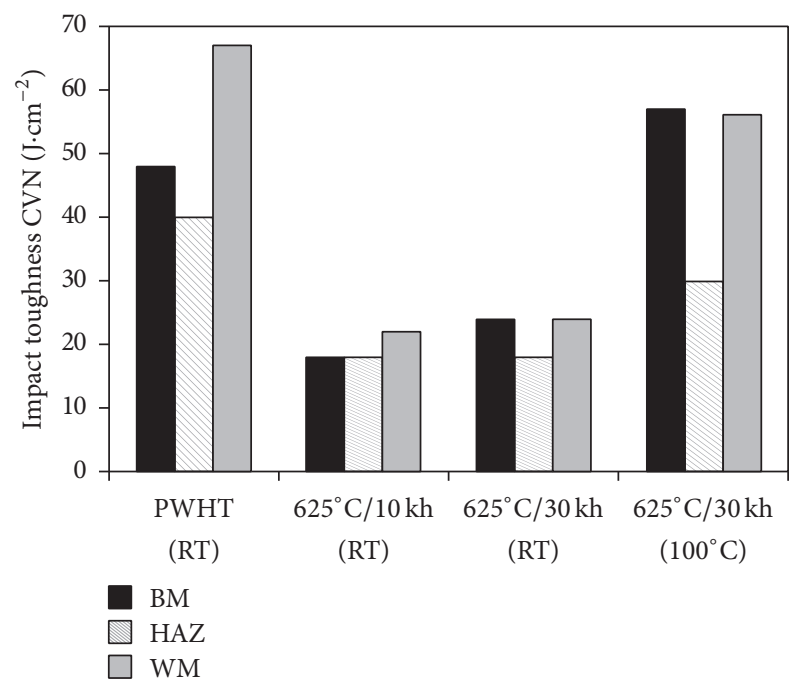

FIGURE 8: Variation of impact toughness values in dependence of CB2 weld region, its material state and testing temperature. CVN values according to [9].

degradation of its microstructure including coarsening of secondary phase precipitates [22]. The observed negligible differences in RT CVN values of the long-term aged states are likely caused by mutually similar level of microstructure degradation of these material states (see Figures 3 and 4). This idea can be supported by the results of other authors [2123] who also found out that the most remarkable changes in microstructure of ferritic creep-resistant steel proceed during the first several thousand hours of its thermal exposure and afterwards its microstructure and properties undergo only very slow long-term degradation due to high thermal stability of these materials. Summarizing the effects of weld region on resulting impact toughness of all tested material states, it can be concluded that the most significant differences in CVN values were revealed for the PWHT state tested at RT and for the $625^{\circ} \mathrm{C} / 30 \mathrm{kh}$ aged state tested at $100^{\circ} \mathrm{C}$. Hence subsequent fractographic observations (Figure 9) were focused on the fracture surfaces of broken impact test specimens showing the most pronounced differences in their CVN values in order to reveal substantial differences in fracture mechanisms related to the specific weld regions and their material states. The fracture surfaces of CVN samples in PWHT state after the impact testing at RT with the notch locations in BM and WM are shown in Figures 9(a) and 9(b), respectively. The fracture surfaces exhibit mixed fracture features characterized by the presence of transgranular quasi-cleavage facets as well as ductile dimple areas. In contrast, the fracture mode of the BM sample tested at RT after $30 \mathrm{kh}$ of ageing at $625^{\circ} \mathrm{C}$ (Figure 9(c)) is almost exclusively formed of transgranular quasi cleavage with coarse facets indicating increased embrittlement of the material by thermal degradation. Moreover, the fracture surface in Figure 9(c) contains also clearly visible secondary cracks and some cleavage reinitiation sites. Similar fracture characteristics are shown in Figure 9(d) which corresponds to the broken CVN sample from the WM region with the same average value of impact toughness (Figure 8 ). To the contrary, Figure 9(e) represents the SEM fractograph of the long-term aged sample from the WM region after impact testing at $100^{\circ} \mathrm{C}$. In this case, the significant fracture features are represented by ductile dimple tearing areas. Such manifestation of fracture behaviour at increased temperature is quite common in ferritic steel and it can generally be related to its thermally enhanced plasticity via increasing mobility of free dislocations in steel matrix. The fracture surface appearance for WM tested at $100^{\circ} \mathrm{C}$ (Figure 9(e)) indicates that the impact test was carried out above brittle-ductile transition region. Indeed, Buršák et al. [24] reported the T35 value (i.e., transition temperature corresponding to the $\mathrm{CVN}$ value equal to $35 \mathrm{~J} \cdot \mathrm{cm}^{-2}$ ) of long-term service exposed $\mathrm{Cr}-\mathrm{Mo}-\mathrm{V}$ creepresistant steel to be about $52^{\circ} \mathrm{C}$. However, in the case of longterm aged $\mathrm{HAZ}$ region tested at $100^{\circ} \mathrm{C}$ (Figure $9(\mathrm{f})$ ) showing notably lower CVN value than that of WM (Figure 8), the fracture surface still exhibits considerable amount of brittle quasi-cleavage features that can be directly related to its increased microstructural heterogeneity enhancing thermal degradation during long-term ageing exposure.

3.2.2. Creep Rupture and Hardness Test. Creep rupture data obtained for studied CB2 weldment creep tested at $625^{\circ} \mathrm{C}$ in both the PWHT state and the preaged $\left(625^{\circ} \mathrm{C} / 30 \mathrm{kh}\right)$ state and also for the $\mathrm{CB} 2 \mathrm{BM}$ preaged at the same conditions are shown in Figure 10. After the creep tests, the as-crept specimens were longitudinally sectioned and metallographically prepared for further investigations including macroscopic observations, cross-weld hardness measurements, and fractographic analyses.

The observed creep rupture behaviour (Figure 10) generally indicates gradual increase of creep rupture time for all the creep tested $\mathrm{CB} 2$ materials (i.e., the preaged CB2 $\mathrm{BM}$ as well as the CB2 welded joints in both the PWHT and preaged conditions) with decreasing applied stress. The CB2 BM exhibited the longest creep rupture lives for all the applied stresses, whereas both welded joints exhibited worse creep life performance. According to numerous research findings, for example $[25,26]$, the most common failure type of welded joints of ferritic creep-resistant steel during long-term service or laboratory creep exposure is related to so-called "type IV failure" in its intercritical HAZ (i.e., the region of $\mathrm{BM}$ heated up to the temperature range between $\mathrm{Ac}_{1}$ and $\mathrm{Ac}_{3}$ critical transformation temperatures during welding) due to its local microstructure degradation by incomplete ferrite-to-austenite transformation and thus subboundary hardening degradation. In general, the longterm creep exposure characterized by long creep life (i.e., long time to rupture) takes place for a selected material in creep conditions (temperature, applied stress) activating low stress regime (LSR) creep deformation mechanisms causing very slow plastic deformation. However, accelerated creep tests (ACT) in laboratory conditions with relatively short creep rupture lives are commonly performed in high stress regime (HSR). Some studies, for example [27-29], on creep behaviour of $9 \mathrm{Cr}$ creep-resistant steel at considered creep temperature indicated transition stress separating the HSR and LSR to be about $100 \mathrm{MPa}$. Thus, the selected applied 


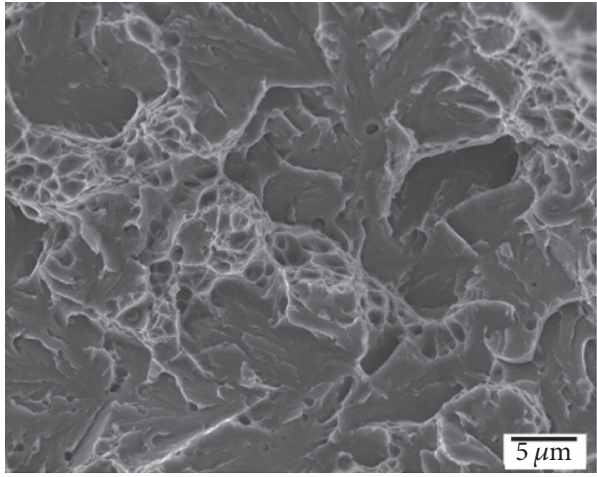

(a)

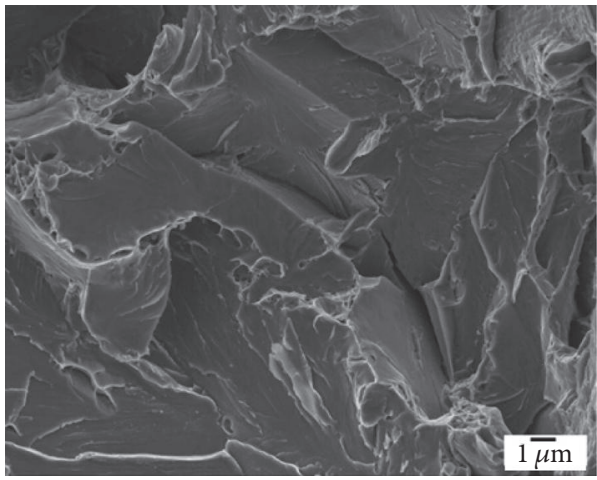

(c)

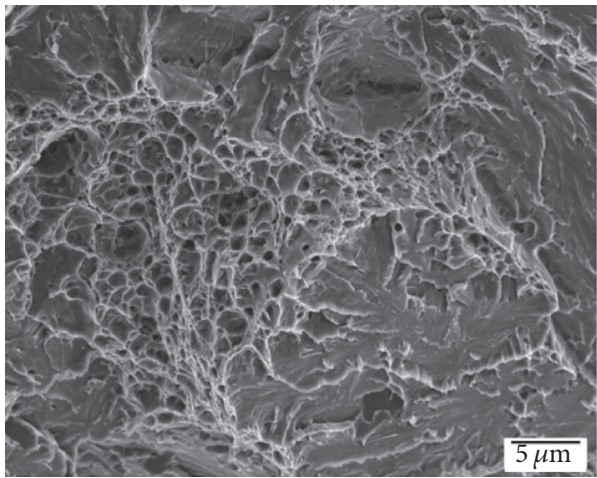

(e)

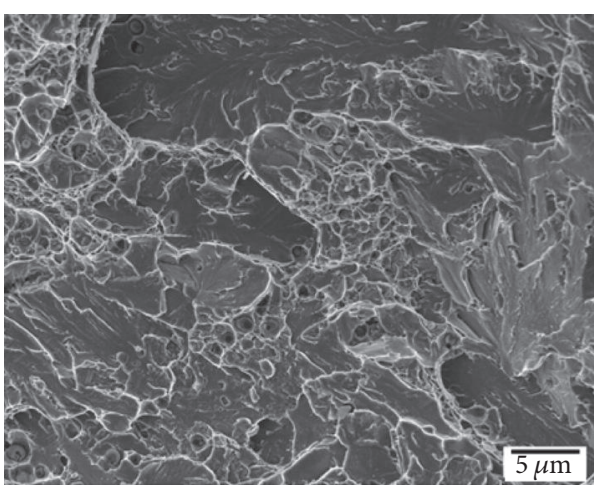

(b)

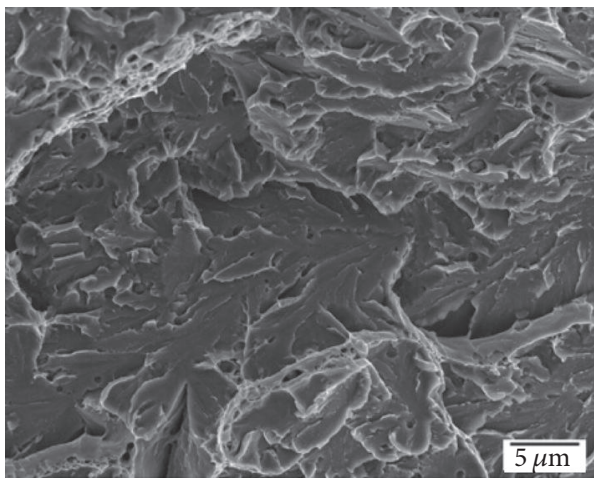

(d)

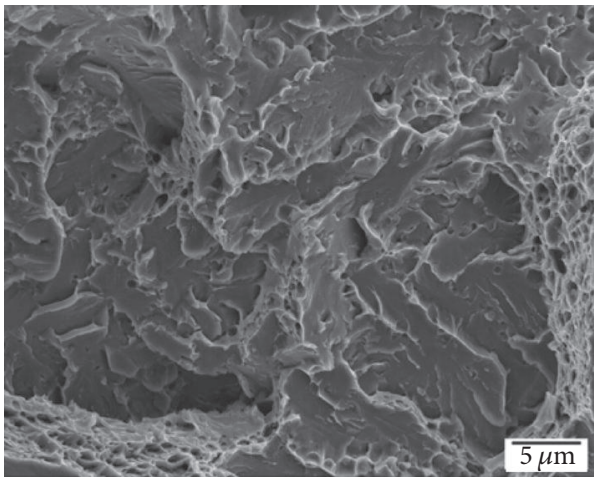

(f)

FIGURE 9: Fracture surfaces of CVN samples after impact toughness tests performed for individual weld regions, material states, and testing conditions: BM, PWHT, and RT (a); WM, PWHT, and RT (b); BM, $625^{\circ} \mathrm{C} / 30 \mathrm{kh}$, and RT (c); WM, $625^{\circ} \mathrm{C} / 30 \mathrm{kh}$, and RT (d); WM, $625^{\circ} \mathrm{C} / 30 \mathrm{kh}$, and $100^{\circ} \mathrm{C}(\mathrm{e}) ; \mathrm{HAZ}, 625^{\circ} \mathrm{C} / 30 \mathrm{kh}$, and $100^{\circ} \mathrm{C}(\mathrm{f})$.

stresses for creep testing in present investigation included the stress range around estimated HSR-to-LSR transition. Beside the obtained creep rupture data (Figure 10), the welds failure types occurring in dependence on used creep conditions were identified by macroscopic observations of metallographically prepared (ground, polished, and etched) longitudinal sections of fractured cross-weld creep specimens after the creep rupture tests. Figure 11 clearly shows that at the highest applied stress of $120 \mathrm{MPa}$, the creep fracture occurred in WM is being referred to as "type I failure" (Figure 11(a)), whereas at both of the lower stresses $(80 \mathrm{MPa}, 100 \mathrm{MPa})$ the failure occurrence shifted to $\mathrm{FZ}$ at the WM/HAZ interface indicating "type III failure" (Figures 11(b) and 11(c)) according to Schüller's classification [30]. The creep failure in preaged $\mathrm{BM}$ is shown in Figure 11(d) for reference. Schuler et al. [31] investigated CB2 welded joints produced using two filler metals with different nickel content aiming for comparison of their creep performance. They indicated failure mode transition from $\mathrm{WM}$ at $120 \mathrm{MPa}$ to $\mathrm{BM}$ at $100 \mathrm{MPa}$. In our present study, the failure mode transition occurred in both "only PWHT processed" as well as in "long-term preaged" weldments. It may be likely related not only to the above-discussed stress-dependent deformation mechanism transition but also to several other welding-metallurgical 


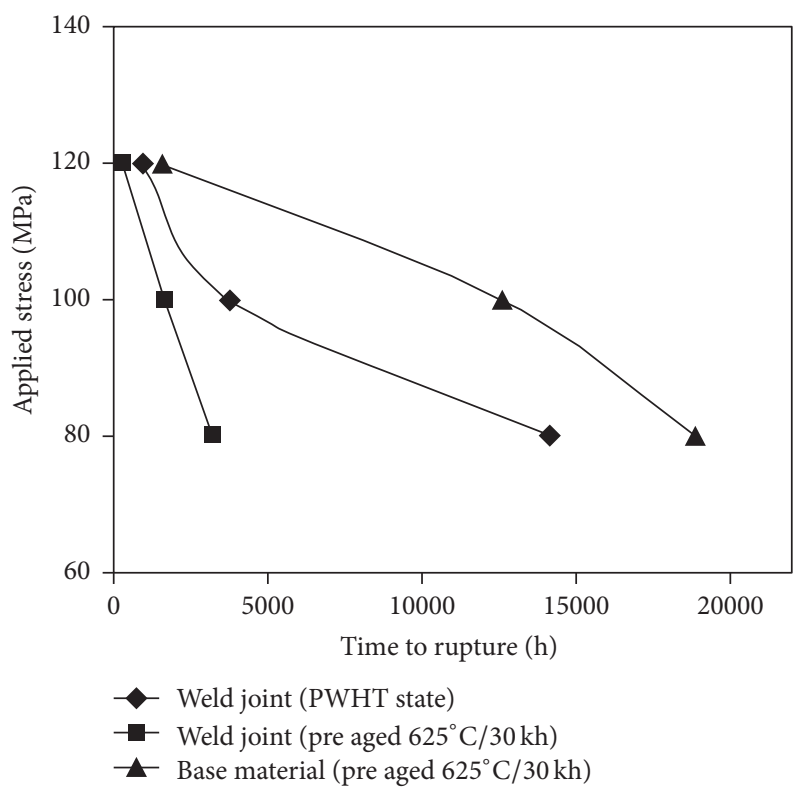

FIGURE 10: Comparison of creep rupture data obtained from creep tests at $625^{\circ} \mathrm{C}$ for $\mathrm{CB} 2$ preaged base material and its welded joint in both PWHT and preaged condition.

factors influencing local chemical and microstructural characteristics of the studied weldment. In general, the "type III failure" mode occurrence in creep conditions has typically been observed in dissimilar weldments exhibiting specific redistribution of their interstitial alloying elements (mainly carbon and nitrogen) during the heat treatment and/or creep exposure. The occurrence of "type III failure" in CB2 welded joint studied in present investigation might also be related to similar redistribution phenomena of boron between BM and WM as well as specific boron alloying effects on the local FZ microstructure (Figure 12). The occurrence of the observed failure mode transition is likely to be related to different propensity of individual weld regions and their microstructures for the localization of creep deformation depending on the applied stress (Figure 11). The differences between the BM and WM chemical compositions may be another important factor influencing the plastic deformation resistance of individual weld regions. The observed rapid softening of higher nickel and lower boron containing WM at the highest applied stress could be related to the higher propensity of nonequilibrium weld microstructure to its degradation by enhanced secondary phase coarsening (compare Figures 5 and 6), dynamic recovery processes, and dislocationcontrolled creep deformation localization leading to final high deformation failure (see Figure 11(a)). In contrast, at lower stresses very low deformation failures occurred in fusion zone at the WM/HAZ interface (Figures 11(b) and $11(c))$. Unlike the previous case, the occurrence of such extremely brittle creep fractures is likely related to local substructural degradation driven by gradual diffusion-controlled alloying elements redistribution (presumably boron) within the fusion zone between the WM and BM during the weld preparation and subsequent exposure leading to the observed failure (Figure 12). The detailed fracture path and creep cavity analyses of broken creep test specimens clearly indicated quasi-brittle intergranular creep fracture characteristics for creep tests performed at $100 \mathrm{MPa}$ and $80 \mathrm{MPa}$ (see Figures 13 and 14). In contrast, the creep tests of both the CB2 weldment and weld-free BM performed at $120 \mathrm{MPa}$ resulted in mixed intergranular/transgranular shear fractures corresponding well to HSR creep deformation (see Figures 15 and 16).

In order to estimate local mechanical properties variation across the studied weldments after individual creep tests performed at different testing conditions, cross-weld hardness (HV10) profiles were determined with respect to the fusion line position (Figure 17). Performed hardness profile measurements indicated different level of softening or even small hardening effects on mutual fracture counterparts. Such behaviour may indicate the local areas of either suppressed or enhanced precipitation (e.g., see the right portions of Figures $12(\mathrm{a})$ and $12(\mathrm{~b})$ ) promoting combined softening/embrittling effects leading to low deformation creep failures in low stress conditions. Significant scattering of hardness values within creep specimen gauge lengths can likely be explained by notable heterogeneity of CB2 weld HAZ region (Figure 1(c)) compared to CB2 BM (Figure 1(a)). Therefore, only the BM samples in the form of thin foils prepared from both the PWHT and preaged $\left(625^{\circ} \mathrm{C} / 30 \mathrm{kh}\right)$ and creep-exposed $\left(625^{\circ} \mathrm{C} / 80 \mathrm{MPa}, 18864 \mathrm{~h}\right)$ material states were subjected to substructural TEM observations (Figure 18). The as-crept sample was taken from the area located approximately $5 \mathrm{~mm}$ beneath creep fracture surface. By comparison of TEM images in Figure 18 it can be stated that the CB2 BM in PWHT state exhibits highly tempered martensitic lath substructure (Figure 18(a)), whereas its preaged and creepexposed substructure exhibits notable recovery features and coarsening of secondary phase precipitates (Figure 18(b)). The observed substructural changes correlate well with creep rupture strength degradation and failure mode transition of creep-exposed CB2 welds studied in present investigation.

\section{Conclusions}

The effects of long-term ageing of $9 \mathrm{Cr}-1.5 \mathrm{Mo}-1 \mathrm{Co}-\mathrm{VNbBN}$ (CB2) steel weldment on its impact toughness, creep rupture behaviour, and cross-weld hardness were studied in relation to microstructure and fracture characteristics. The obtained results can be summarized in the following conclusions:

(i) Performed long-term ageing expositions at $625^{\circ} \mathrm{C}$ for 10 and 30 thousand hours resulted in significant decrease of room-temperature Charpy V-notch impact toughness $(\mathrm{CVN})$ values in all studied weld regions compared to those of the initial PWHT state. However, the individual weld regions such as WM, HAZ, and BM exhibited different measure of impact toughness degradation corresponding to differing level of their local microstructure degradation. The most deteriorated CVN values of all weld regions in all material states were obtained for overheated HAZ region with the most heterogeneous microstructure containing nonequilibrium delta-ferrite residuals. 


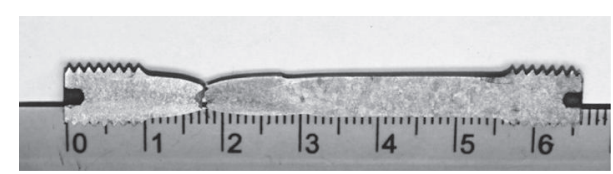

(a)

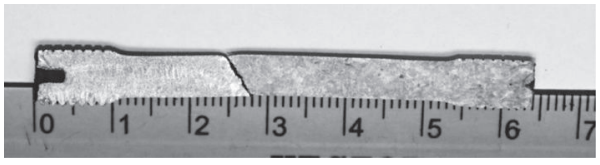

(c)

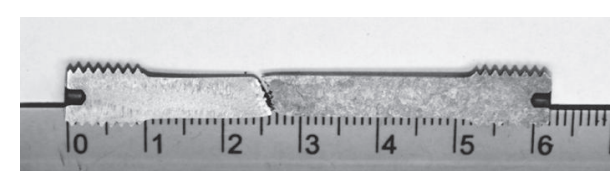

(b)

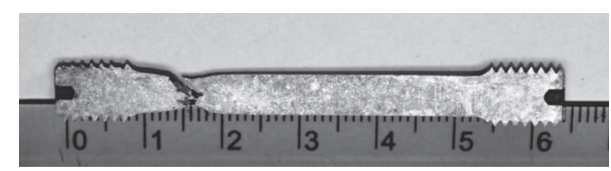

(d)

FIGURE 11: Longitudinal sections of creep specimens counterparts indicating the following: "type I failure" in WM after creep test of CB2 welded joint at $625^{\circ} \mathrm{C} / 120 \mathrm{MPa}$ (a), "type III failure" in FZ after creep test at $625^{\circ} \mathrm{C} / 100 \mathrm{MPa}$ (b), "type III failure" in FZ after creep test at $625^{\circ} \mathrm{C} / 80 \mathrm{MPa}(\mathrm{c})$, and failure in $\mathrm{CB} 2 \mathrm{BM}$ of weld-free specimen after creep test at $625^{\circ} \mathrm{C} / 120 \mathrm{MPa}$ (d).

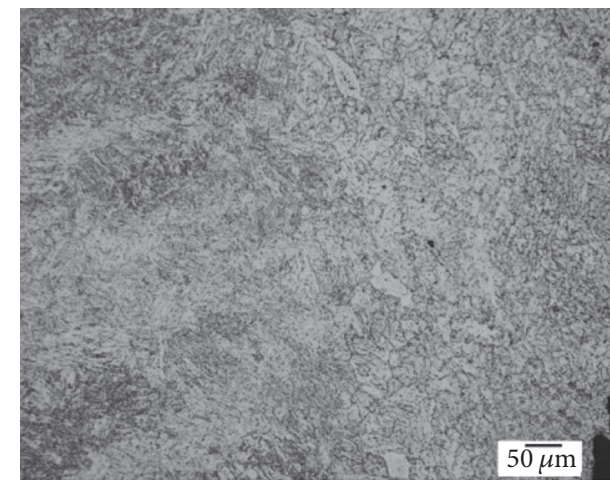

(a)

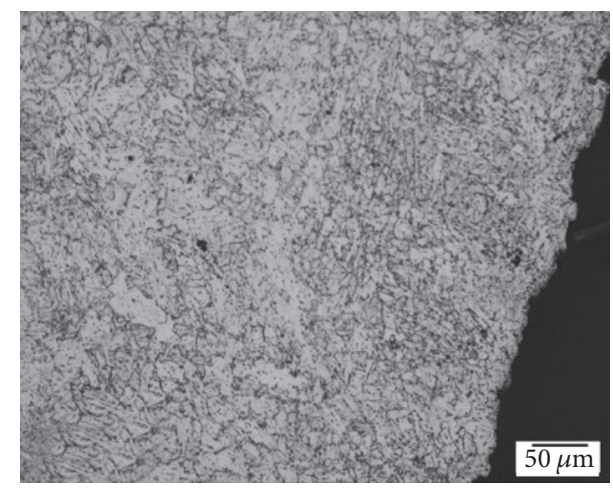

(b)

FIGURE 12: Light-optical microstructures beneath "type III failure" of CB2 weldment crept at $625^{\circ} \mathrm{C} / 80 \mathrm{MPa}$ for $14145 \mathrm{~h}$ showing the following: microstructural gradient between WM and FZ (a) and microstructure of FZ in detail (b).

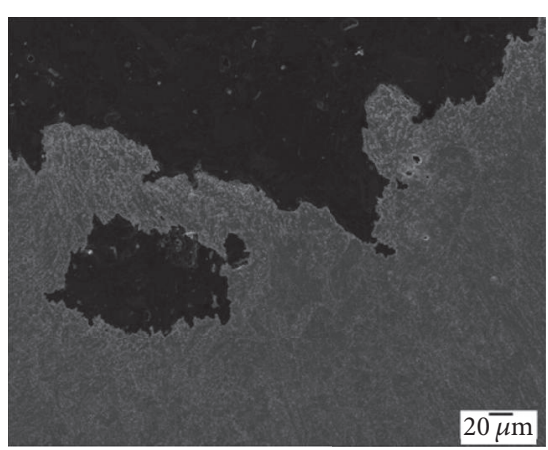

(a)

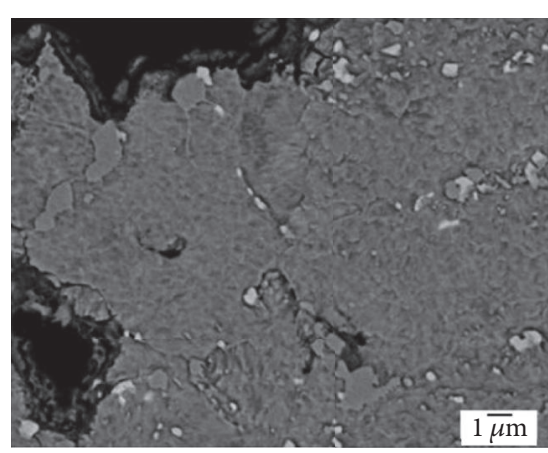

(b)

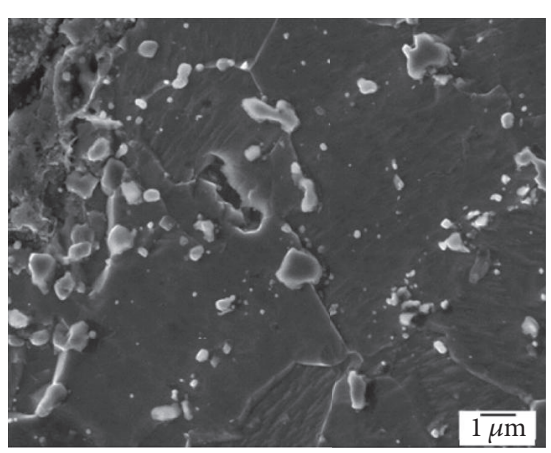

(c)

FIGURE 13: Fracture path $(\mathrm{a}, \mathrm{b})$ and creep cavity $(\mathrm{b}, \mathrm{c})$ analyses of CB2 weldment ruptured by "type III failure" after the creep test at $625^{\circ} \mathrm{C}$, $100 \mathrm{MPa}$.

(ii) The highest room-temperature CVN value in PWHT state was measured in the WM which might be related to its finer initial microstructure, self-tempering effects of temper-bead welding procedure, the lower boron and higher nickel content compared to the BM, and the presence of globular inclusions promoting the formation of ductile dimples during plastic deformation. (iii) The most significant decreases of room-temperature CVN values corresponding to all individual weld regions were observed after the ageing of studied weldment at $625^{\circ} \mathrm{C}$ for 10 thousand hours. A variation in CVN values with further ageing up to 30 thousand hours was rather insignificant. This finding was additionally supported by microstructural observations showing the most significant microstructural changes 


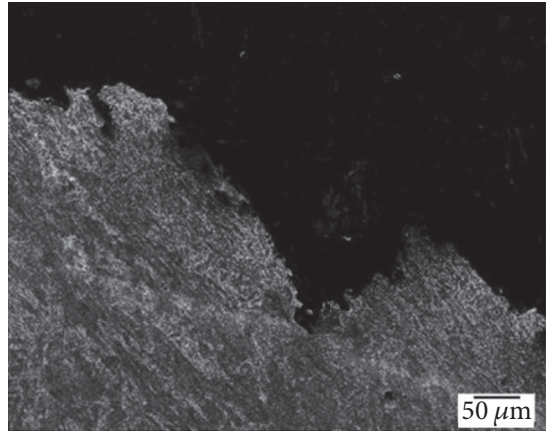

(a)

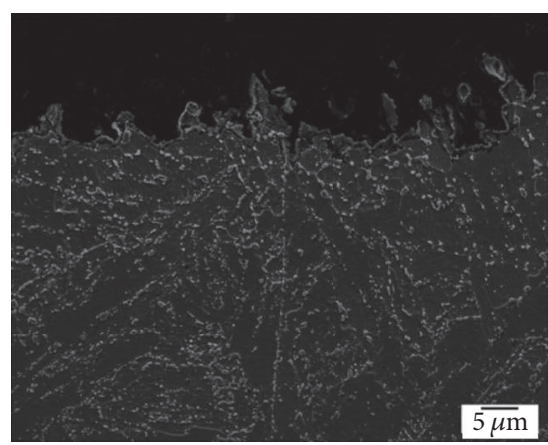

(b)

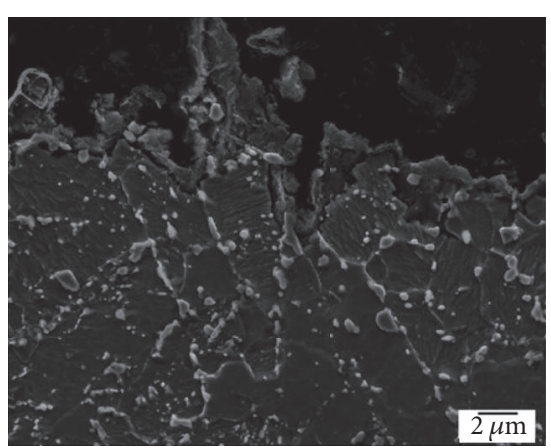

(c)

FIgURE 14: Fracture path (a, b, c) and creep cavity (c) analyses of CB2 weldment ruptured by "type III failure" after the creep test at $625^{\circ} \mathrm{C}$, $80 \mathrm{MPa}$.

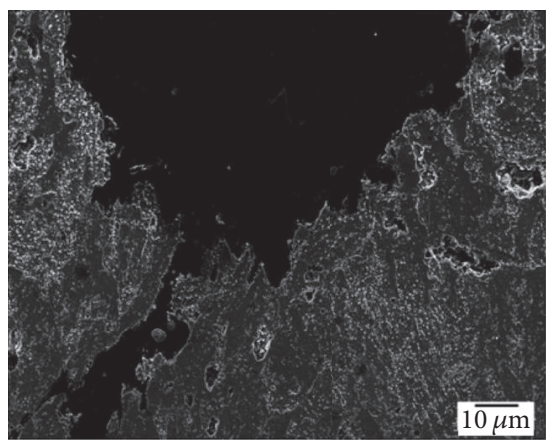

(a)

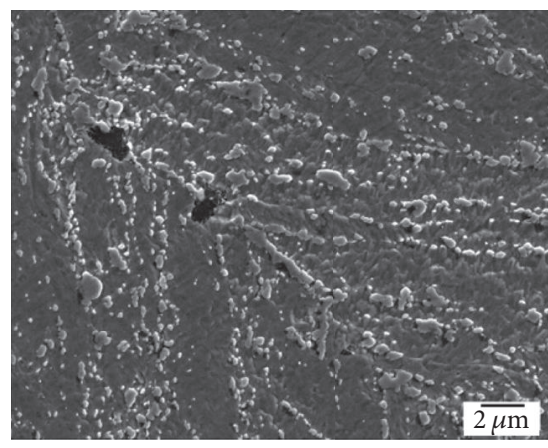

(b)

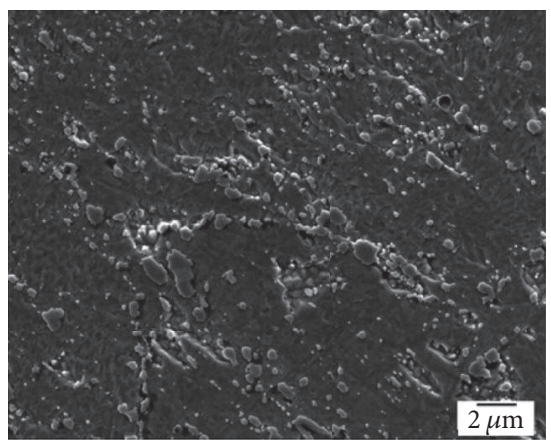

(c)

FIGURE 15: Fracture path (a) and creep cavities in WM (b) and nonruptured necked FZ (c) of CB2 weldment ruptured in WM by "type I failure" after the creep test at $625^{\circ} \mathrm{C}, 120 \mathrm{MPa}$.

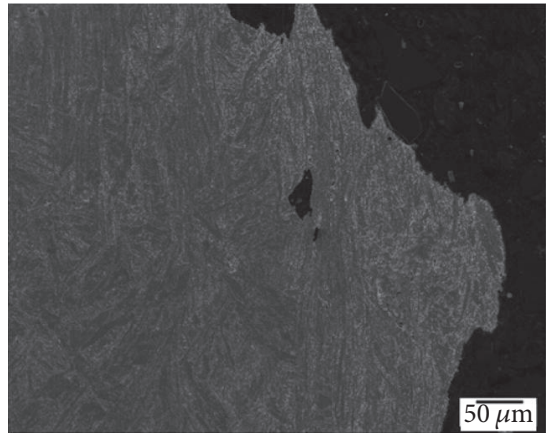

(a)

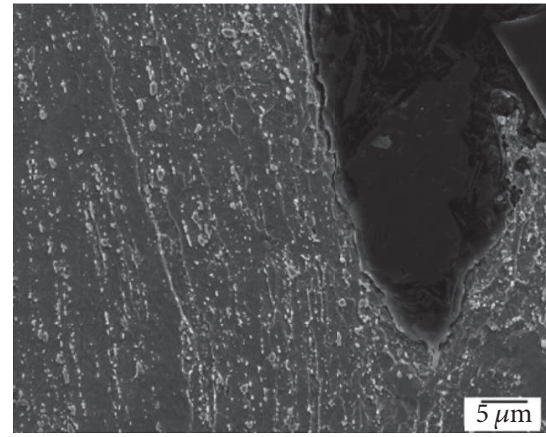

(b)

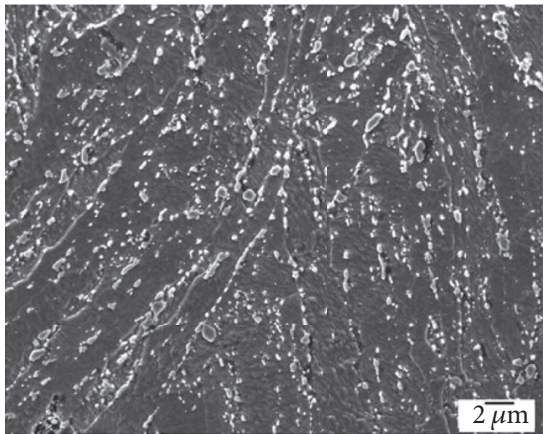

(c)

FIGURE 16: Fracture path $(\mathrm{a}, \mathrm{b})$ and creep cavity $(\mathrm{c})$ analyses of CB2 BM specimen ruptured by high deformation shear failure after the creep test at $625^{\circ} \mathrm{C}, 120 \mathrm{MPa}$.

(matrix recovery and precipitate coarsening) already after the first period of ageing followed by only small microstructural changes with increasing ageing duration.

(iv) According to phase analyses performed on TEM carbon extraction replicas, only two types of the precipitates were revealed in PWHT state, namely, fine intragranular $\mathrm{MX}$ carbonitrides $(\mathrm{M}=\mathrm{V}, \mathrm{Nb}, \mathrm{Cr}$; $\mathrm{X}=$
$\mathrm{C}, \mathrm{N}$ ) and large intergranular $\mathrm{Cr}$-rich $\mathrm{M}_{23} \mathrm{C}_{6}$ carbides. In contrast, during subsequent long-term ageing at $625^{\circ} \mathrm{C}$ the additional precipitation of newly formed secondary phase particles has been revealed, namely, the $(\mathrm{Fe}, \mathrm{Cr})_{2} \mathrm{Mo}$ based Laves phase, $\mathrm{Cr}(\mathrm{V}, \mathrm{Nb}) \mathrm{N}$ type $\mathrm{Z}$-phase, and Nb-rich MC carbides. The occurrence of all these secondary phases qualitatively agrees well with performed equilibrium thermodynamic calculations. 


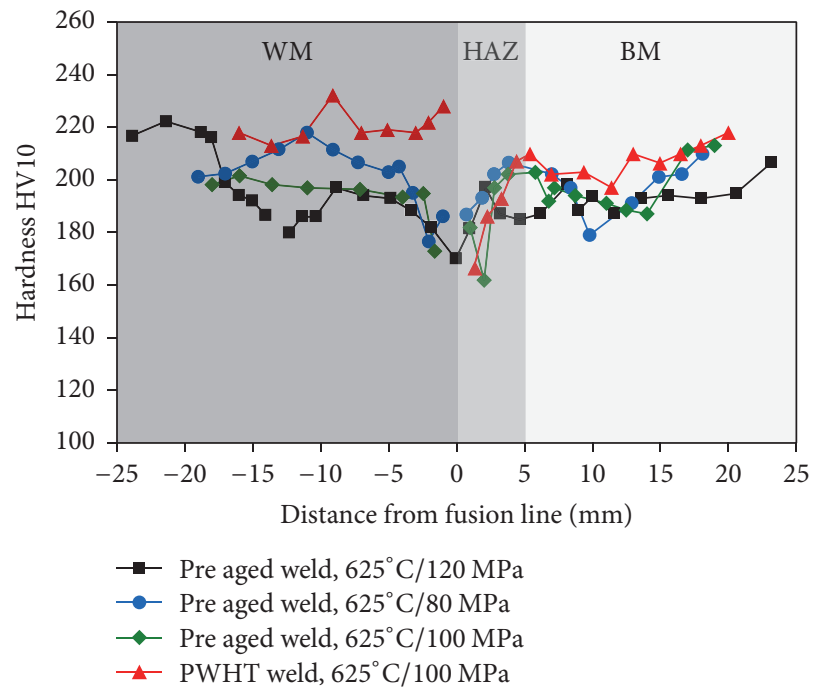

FIgURE 17: Cross-weld hardness profiles of several creep-exposed CB2 weldments.

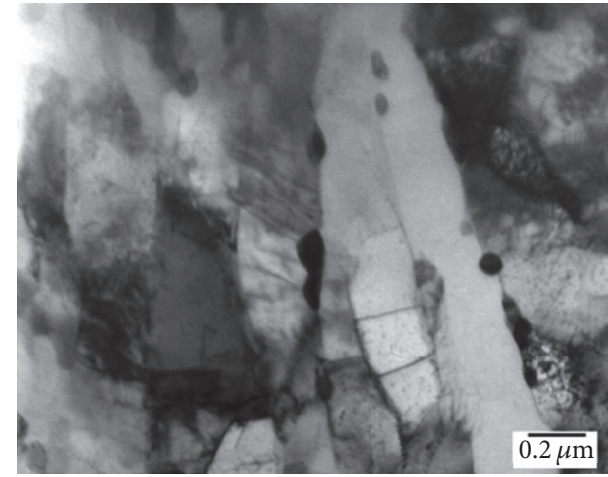

(a)

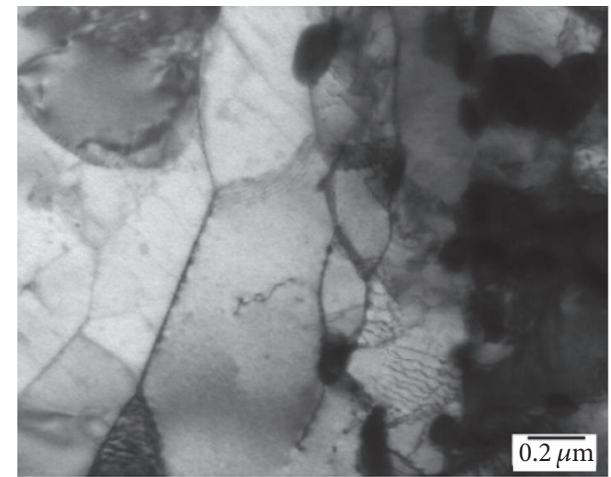

(b)

FIGURE 18: Bright field TEM images of CB2 BM substructure in initial PWHT state (a) and after the creep test at $625^{\circ} \mathrm{C}, 80 \mathrm{MPa}$ for $18864 \mathrm{~h}$ of the preaged $\left(625^{\circ} \mathrm{C} / 30 \mathrm{kh}\right)$ material (b).

(v) In comparison to the PWHT state, experimentally determined mean chemical composition of individual secondary phases indicated their clear compositional variations in both ageing and calculated equilibrium condition. These changes were related to the increase of chromium content in $\mathrm{M}_{23} \mathrm{C}_{6}$ carbides at the expense of other alloying elements. The Zphase created at the expense of MX particles exhibited notably higher vanadium content in the aged condition compared to thermodynamic prediction. The experimental composition of Nb-rich MC carbides in the aged condition exhibited much lower niobium content compared to equilibrium calculation. In contrast, the chemical composition of Laves phase was found to be very similar to theoretically calculated composition. Thus all these findings can likely be related to different precipitation kinetics and evolution of individual secondary phases.

(vi) The obtained creep rupture data indicated gradual increase of creep rupture time for all the creep tested
$\mathrm{CB} 2$ materials (i.e., the preaged $\mathrm{CB} 2 \mathrm{BM}$ as well as the CB2 welded joints in both the PWHT and preaged conditions) with decreasing applied stress. The CB2 $\mathrm{BM}$ exhibited the longest creep rupture lives for all the applied stresses, whereas both welded joints exhibited worse creep life performance.

(vii) For both the PWHT processed and the preaged welded joints, the failure mode transitions were observed. At the applied stress of $120 \mathrm{MPa}$, the creep fracture occurred in WM, whereas at lower stresses the failure occurred in FZ at the WM/HAZ interface. The observed failure mode transition may likely be related to several factors such as stress-dependent creep deformation mechanism transition, different propensity of individual weld regions for creep deformation localization, and strain-enhanced substructural coarsening and alloying elements redistribution between BM and WM indicated by performed microstructural and fracture path observations. 
(viii) It can be generally stated that short-term creep rupture tests performed at the highest applied stress exhibited high deformation failures, whereas rapid plasticity decrease was observed for the long-term creep tests performed at lower applied stresses. This observation is believed to be directly related to the same aforementioned factors affecting the observed stress-dependent failure mode changes.

(ix) Cross-weld hardness profiles exhibited notable scattering of hardness values due to significant microstructural heterogeneity of studied weldment. However, the hardness profile measurements were revealed to be a suitable tool for the indication of local areas with enhanced creep degradation within creep-exposed weldments. The major fracture mechanisms revealed in present study corresponded well with observed microstructure degradation and were mainly related to transgranular quasi cleavage and intergranular creep cracking in impact and creep testing conditions, respectively.

\section{Competing Interests}

The authors declare that they have no competing interests.

\section{Acknowledgments}

The present work has been supported by the Slovak National Scientific Grant Agency VEGA under Grant nos. 2/0151/16 and 2/0153/15, International Collaborative Project COST Action 536, and also Bilateral Project SAV-AVCR 15-11. Thanks are also due to Dr. A. Výrostková (IMR SAS retired, Košice, Slovakia) for the TEM replicas analyses, fractography, and helpful discussions.

\section{References}

[1] F. Abe, M. Tabuchi, H. Semba et al., "Feasibility of MARBN steel for application to thick section boiler components in USC power plant at $650{ }^{\circ} \mathrm{C}$," in Proceedings of the 5th International Conference on Advances in Materials Technology for Fossil Power Plants, pp. 92-106, Marco Island, Fla, USA, October 2007.

[2] S. S. M. Tavares, J. M. Pardal, G. C. Souza et al., "Study of cracks in the weld metal joint of p91 steel of a superheater steam pipe," Engineering Failure Analysis, vol. 56, pp. 464-473, 2015.

[3] C. Pandey, A. Giri, and M. M. Mahapatra, "Effect of normalizing temperature on microstructural stability and mechanical properties of creep strength enhanced ferritic P91 steel," Materials Science and Engineering A, vol. 657, pp. 173-184, 2016.

[4] M. Cieśla and G. Junak, "The influence of load history on durability of P92 steel used for the construction of energy pipelines," Archives of Metallurgy and Materials, vol. 60, no. 3, pp. 1853-1858, 2015.

[5] L. Falat, L. Čiripová, J. Kepič, J. Buršík, and I. Podstranská, "Correlation between microstructure and creep performance of martensitic/austenitic transition weldment in dependence of its post-weld heat treatment," Engineering Failure Analysis, vol. 40, pp. 141-152, 2014.
[6] L. Falat, J. Kepič, L. Čiripová, P. Ševc, and I. Dlouhý, “The effects of postweld heat treatment and isothermal aging on T92 steel heat-affected zone mechanical properties of T92/TP316H dissimilar weldments," Journal of Materials Research, vol. 31, no. 10, pp. 1532-1543, 2016.

[7] F. Abe, M. Tabuchi, S. Tsukamoto, and T. Shirane, "Microstructure evolution in HAZ and suppression of Type IV fracture in advanced ferritic power plant steels," International Journal of Pressure Vessels and Piping, vol. 87, no. 11, pp. 598-604, 2010.

[8] COST Action 536 International Collaborative Project, Alloy Development for Critical Components of Environmentally Friendly Power Plant, Project Head: Professor John Hald, Technical University of Denmark, Lyngby, Denmark, 2011.

[9] L. Falat, A. Výrostková, J. Kepič, and L. Čiripová, “The influence of isothermal annealing on degradation of mechanical properties of homogeneous weldment of the 9Cr-Mo steel," Chemicke Listy, vol. 106, no. 3, pp. s405-s406, 2012.

[10] A. Výrostková, L. Falat, J. Kepic, P. Brziak, and J. Pecha, "Microstructure and fracture of 9\%CR-MO-CO-B steel (CB2) weldment after isothermal ageing," in Proceedings of the 19th International Conference on Metallurgy and Materials (METAL '10), pp. 409-414, Rožnov pod Radhoštěm, Czech Republic, May 2010.

[11] http://www.thermocalc.com/.

[12] A. Kroupa, J. Havránková, M. Coufalová, M. Svoboda, and J. Vřešt'ál, "Phase diagram in the iron-rich corner of the Fe-CrMo-V-C system below $1000 \mathrm{~K}$," Journal of Phase Equilibria, vol. 22, no. 3, pp. 312-323, 2001.

[13] A. Zieliński, G. Golański, and M. Sroka, "Assessment of microstructure stability and mechanical properties of X10CrWMoVNb9-2 (P92) steel after long-term thermal ageing for high-temperature applications," Kovove Materialy, vol. 54, no. 1, pp. 61-70, 2016.

[14] V. Sklenička, K. Kuchařová, M. Svobodová, M. Kvapilová, P. Král, and L. Horváth, "Creep properties in similar weld joint of a thick-walled P92 steel pipe," Materials Characterization, vol. 119, pp. 1-12, 2016.

[15] D. Meng, F. Lu, H. Cui, Y. Ding, X. Tang, and X. Huo, "Investigation on creep behavior of welded joint of advanced 9\%Cr steels," Journal of Materials Research, vol. 30, no. 2, pp. 197-205, 2015.

[16] D. Jandová, J. Kasl, and E. Chvostová, "Microstructure of CB2 steel before and after long-term creep tests," Materials Science Forum, vol. 782, pp. 311-318, 2014.

[17] C. G. Panait, W. Bendick, A. Fuchsmann, A.-F. GourguesLorenzon, and J. Besson, "Study of the microstructure of the Grade 91 steel after more than 100,000 h of creep exposure at 600॰C," International Journal of Pressure Vessels and Piping, vol. 87, no. 6, pp. 326-335, 2010.

[18] R. Agamennone, W. Blum, C. Gupta, and J. K. Chakravartty, "Evolution of microstructure and deformation resistance in creep of tempered martensitic $9-12 \% \mathrm{Cr}-2 \% \mathrm{~W}-5 \%$ Co steels," Acta Materialia, vol. 54, no. 11, pp. 3003-3014, 2006.

[19] L. Cipolla, H. K. Danielsen, P. E. Di Nunzio, D. Venditti, J. Hald, and M. A. J. Somers, "On the role of $\mathrm{Nb}$ in Z-phase formation in a $12 \%$ Cr steel," Scripta Materialia, vol. 63, no. 3, pp. 324-327, 2010.

[20] K. Sawada, H. Kushima, K. Kimura, and M. Tabuchi, “Z-phase formation and its effect on long-term creep strength in $9-12 \% \mathrm{Cr}$ creep resistant steels," Transactions of the Indian Institute of Metals, vol. 63, no. 2-3, pp. 117-122, 2010. 
[21] F. Abe, "Heat-to-heat variation in long-term creep strength of some ferritic steels," International Journal of Pressure Vessels and Piping, vol. 87, no. 6, pp. 310-318, 2010.

[22] P. Mohyla, Z. Kubon, R. Cep, A. Janasek, and I. Samardzic, "Secondary hardening of low-alloyed creep-resistant steel welds," Metalurgija, vol. 53, no. 1, pp. 25-28, 2014.

[23] K. Sawada, H. Kushima, T. Hara, M. Tabuchi, and K. Kimura, "Heat-to-heat variation of creep strength and long-term stability of microstructure in Grade 91 steels," Materials Science and Engineering A, vol. 597, pp. 164-170, 2014.

[24] M. Buršák, J. Miche', J. Janek, and M. Vojtko, “The contribution to apraisal of residual life cycle of creep resistant low alloy steels," Chemicke Listy, vol. 105, no. 16, pp. s621-s623, 2011.

[25] P. Mayr and H. Cerjak, "The impact of welding on the creep properties of advanced 9-12\% Cr steels," Transactions of the Indian Institute of Metals, vol. 63, no. 2-3, pp. 131-136, 2010.

[26] F. Abe, M. Tabuchi, and S. Tsukamoto, "Metallurgy of type IV fracture in advanced ferritic power plant steels," Materials at High Temperatures, vol. 28, no. 2, pp. 85-94, 2011.

[27] L. Kloc and V. Sklenička, "Transition from power-law to viscous creep behaviour of P-91 type heat-resistant steel," Materials Science and Engineering A, vol. 234-236, pp. 962-965, 1997.

[28] L. Falat, V. Homolová, J. Kepič, M. Svoboda, and A. Výrostková, "Microstructure and properties degradation of P/T 91, 92 steels weldments in creep conditions," Journal of Mining and Metallurgy B: Metallurgy, vol. 48, no. 3, pp. 461-469, 2012.

[29] B. K. Choudhary, "Tertiary creep behaviour of 9Cr-1Mo ferritic steel," Materials Science and Engineering A, vol. 585, pp. 1-9, 2013.

[30] H. J. Schüller, L. Hagn, and A. Woitscheck, "Risse im Schweißnahtbereich von Formstücken aus Heißdampfleitungen-Werkstoffuntersuchungen," Der Maschinenschaden, vol. 47, no. 1, pp. 1-13, 1974.

[31] M. Schuler, S. Baumgartner, R. Schnitzer, and N. Enzinger, "Creep investigation and simulation of CB2 joints using similar rutile CB2 flux-cored wire," Welding in the World, vol. 58, no. 6, pp. 903-913, 2014. 

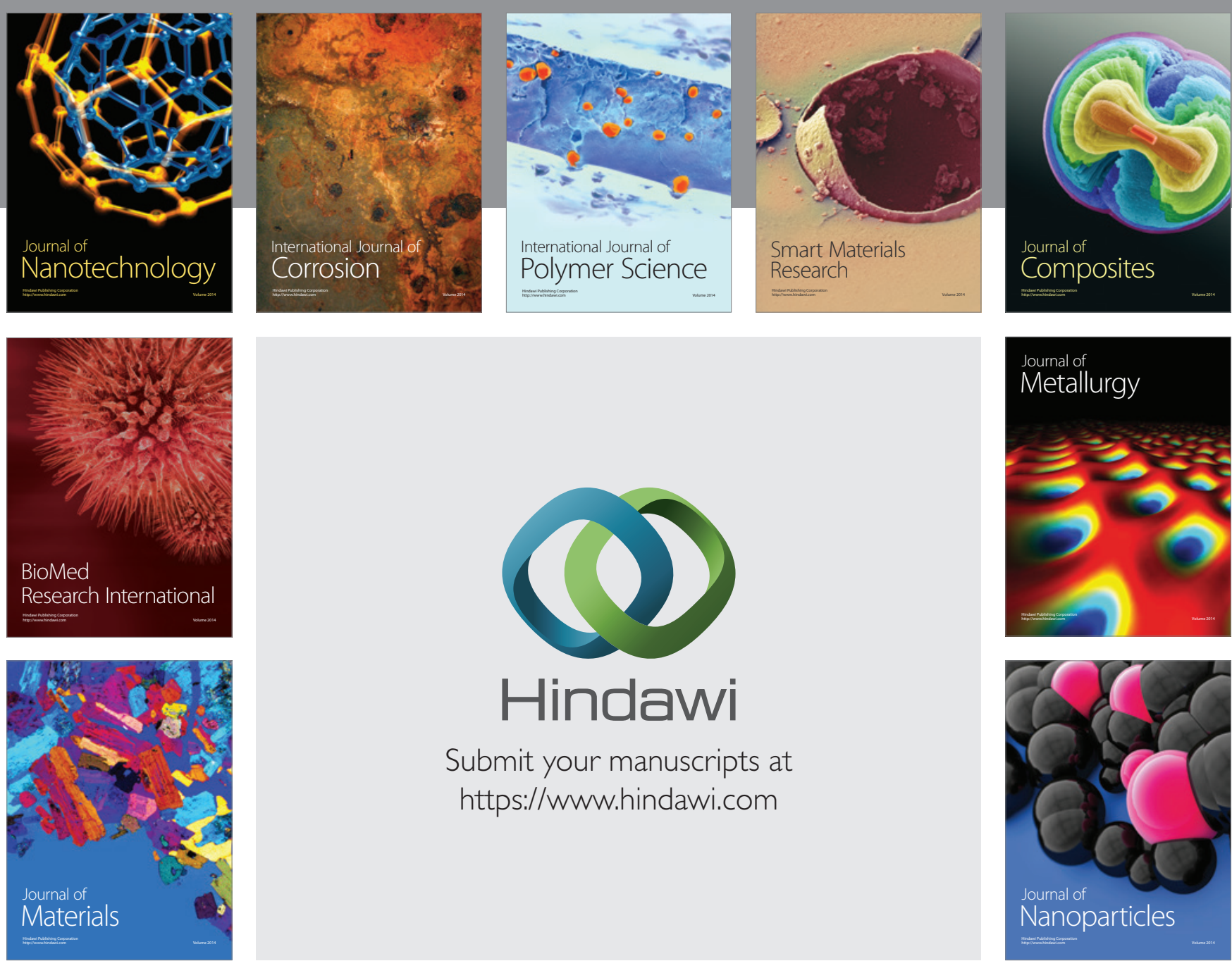

\section{Hindawi}

Submit your manuscripts at

https://www.hindawi.com

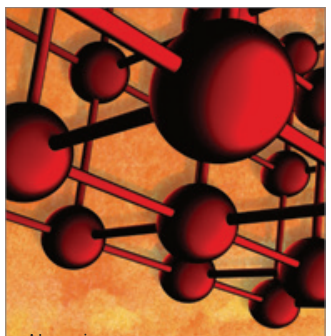

Materials Science and Engineering
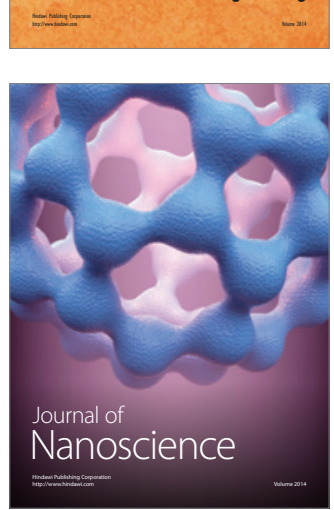
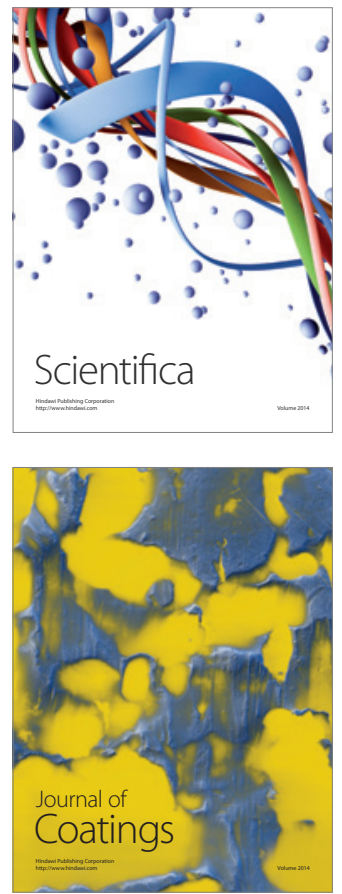
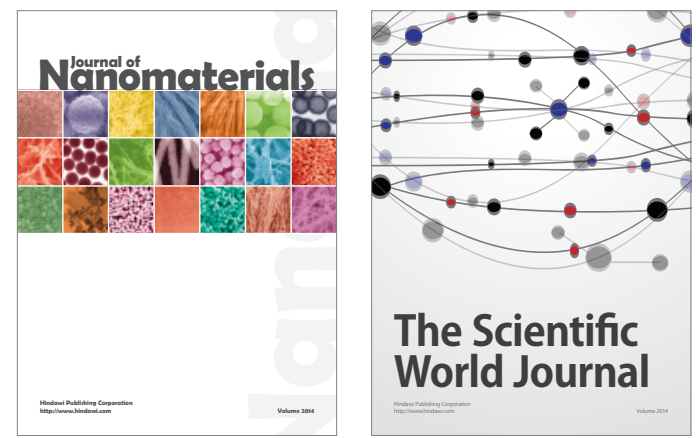

The Scientific World Journal
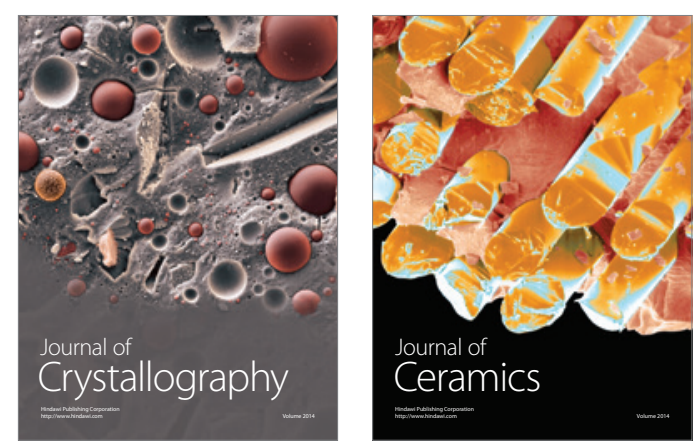
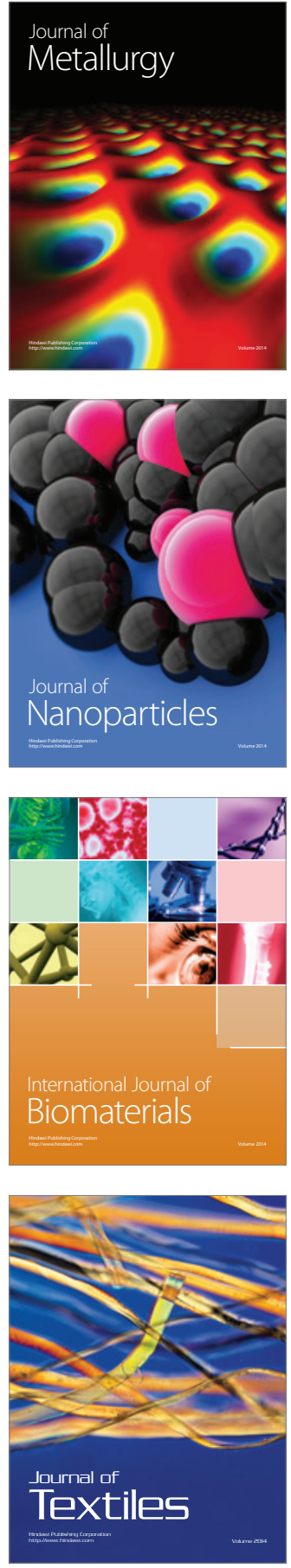